\title{
The Effect of Leadership Style, Work Motivation and Local Culture on Organizational Citizenship Behavior and Civil Servants Performance
}

\author{
Althon Karaman Pongtuluran ${ }^{1)}$, H. Salim Basalamah ${ }^{2)}$, H. Zaenal Arifin ${ }^{3)}$, \\ Jamaluddin Bijang ${ }^{4}$ \\ 1) (Doctoral Student, University of Muslim Indonesia) \\ 2, 3,4) (Faculty of Economics, University of Muslim Indonesia) \\ Corresponding Author: Althon Karaman Pongtuluran
}

\begin{abstract}
This study aims to test and analyze empirically the effect of leadership style, work motivation and local culture on organizational citizenship behavior $(O C B)$ and civil servants performance at 156 civil servants working in Tana Toraja Local Government. The results of the structural equation modeling using AMOS (Analysis of Moment Structures) software Ver.21 provides evidence that the style of leadership, motivation and local culture positive and significant effect on $O C B$. The $O C B$ is a positive and significant effect on civil servants performance. Leadership style and work motivation positive and no significant effect on civil servants performance. The Local culture is a positive and significant on civil servants performance. The mediating roles of $O C B$ are increasingly the leadership style, employee motivation and local culture on civil servants performance
\end{abstract}

Keywords - Leadership style, motivation, local culture, OCB, civil servants performance

\section{Introduction}

Tana Toraja regency administration as one local government organization in the province of South Sulawesi (Indonesia) are increasingly required to stimulate optimal performance of employees that are expected to encourage the development and service activities and further streamline the wheels of government in the region. In line with the utilization of human resources as the basic capital must be followed by the development and renewal of the capabilities and expertise that each organization personnel capable of responding to and sensitive to the direction of the changes. Members of the organization must support the organizational changes (Brown \& Harvey, 2011). The results indicated that the Civil Service has not shown that optimal performance can be seen on Management Performance Index (HPI) civil servants in Tana Toraja, which is at the low predicate. The condition is caused due to lack of motivation given by the head of the regional work units (SKPD), and the limited of the resources both of the financial or human resources to support the implementation of civil service management optimally, as well as the lack of transparency of local governments in carrying out activities related with civil service management. Optimal performance improvement can be done by increasing the high motivation.

Good employee (good citizens) tend to show OCB in the work environment, so that the organization would be better off with their employees who act OCB. Extra-role behavior is a behavior that is very much appreciated when done by an employee although not formally described as improving the effectiveness and viability of the organization. Organizations will not work properly or cannot survive without its members who act as good citizens (Markoczy \& Xin, 2002). To do something good, civil servants are not always driven by things that only benefit him. With the ability to empathize, to understand other people and the environment and can align individual values espoused by the values espoused environment, so it appears that nice behavior is as good citizen (Hardaningtyas, 2004: 5). OCB is a helpful attitude shown by members of the organization, which are constructive, valued by the company but not directly related to individual productivity. OCB is a form of behavior that is an individual choice and initiative, not related to the organization's formal reward system but in aggregate increase the effectiveness of the organization (Podsakoff et al., 2000). Results of previous studies show that there is a positive relationship between transformational leadership and clan culture as well as between transformational leadership and affective commitment. There is no significant relationship between clan cultures, transformational leadership with OCB, yet affective commitment showed a positive and significant impact on OCB and between clan cultures against affective commitment (Kim et al., 2014). Other 
studies prove that personality and organizational culture positive and significant impact on OCB, as well as the OCB effect on employee performance (Darsana, 2013; Sjahruddin \& Normijati, 2013).

\section{Literature Review}

\section{Leadership Style}

Leadership style is the pattern of overall leader acts as perceived by employees (Davis, 2005). Leadership styles representing philosophy, skills and attitudes of political leaders. Leadership is an ability that is inherent in man to lead that depends on various factors, factors both internal and external factors (Winardi, 2000). Leadership is how one affects the behavior of subordinates to cooperate and work productively to achieve organizational goals (Hasibuan, 2006).

\section{Work motivation}

Understanding the motivation is closely related to the emergence of a tendency to do something in order to achieve the goal. There is a strong relationship between the need for motivation, action or behavior, purpose and satisfaction, because any change always thanks to their encouragement. Motivation arises because of the necessity and therefore the act was purposeful achievement of certain goals. If the goal is achieved it will be achieved satisfaction and tend to be repeated, so it is strong and steady. The motivation is the desire to do as a willingness to issue a high level of effort for the organization's goals, conditioned by the effort's ability to satisfy an individual requirement (Robbins, 2002: 55). The views of other scholars explain that the motivation is the force that drives a person who raises and directs employee's behavior (Gibson, 1995).

\section{Local Culture}

Culture is the essence of what is important in the organization, such as the activity of giving orders and prohibitions as well as describe something done and not done that govern the behavior of members. So culture contains what may be done or not to be so it can be regarded as a guideline that is used to run the activities of the organization, (Hofstede, 2010: 21). Culture is a social and regulator controllers running of the organization on the basis of values and beliefs that are shared, so that it becomes the norm group work, and operationally called work culture because it is a guidance and direction employee behavior (Chatab, 2007).

The local wisdom or the local culture translated into Indonesian language means the local culture or local knowledge. The word comes from the Bugis language Toraja, to Riaja, which means people who dwell in the land above. The Dutch colonial government named this tribe in 1909. Tana Toraja tribe famous for funeral rituals, the customs of Tongkonan house and carving wood. Toraja funeral rites are important social events, usually attended by hundreds of people and lasted several days. Toraja tribe is the tribe who settled in the mountains of the northern part of South Sulawesi, Indonesia. Its population is estimated at around 1 million people, with 500,000 of them still live in Tana Toraja, North Toraja Regency, and Mamasa. The majority of the Toraja embraced Christianity, while the majority embraced Islam and animism known (such as Aluk to Dolo). The Indonesian government has recognized this belief as part of Hindu Dharma (religion).

Toraja culture is inseparable from the understanding of the old belief (aluk to dolo) which in manifestation in the form of (aluk) and tradition (adaa'). According to mythology Toraja, the religion (aluk) derived from the top nature i.e from the sky or nature gods brought down to earth known as the round seven religion (aluk sanda pitunna or 7777777) and covers all areas of human life (Kobong, 1992: 19). Understanding of the local culture of Tallu bakaa i.e. wise (kinaa), rich (sugi) and brave (barani) by local government officials only be understood by the dominant cultures do in Toraja. Kinaa (wise) means duties professionally and impartially and to deliver services to the public in an honest, responsive, fast, precise, accurate, and courteous. Sugi (rich) is defined as the ability to implement government policies and programs and maintain and uphold the ethical standards that are noble and give priority to high-quality leadership. Barani (brave) means accountable for actions and performance to the public and make decisions with the principles of expertise and create a work environment that is non-discriminatory.

\section{Organizational Citizenship Behavior}

OCB as individual behavior that is discretionary, which do not directly and explicitly received an award from the formal reward system, and the overall push effectiveness of organizational functions. OCB is free and voluntary; as such behavior is not required by the terms of role or position description, which clearly required under the contract with the organization, but as a personal choice (Podsakoff et al., 2000). The views of other scholars explain OCB as contributions exceed the demands of the role of individuals in the workplace. OCB involves several behaviors include behaviors like helping others, volunteering for extra duties, adhere to the rules and procedures in the workplace (Aldag \& Reschke, 1997; Sjahruddin, H., \& Sudiro, AA 2013), Some important basic thoughts about OCB, namely: free action, spontaneous, voluntary done for the sake of others (coworkers, group, or organization), not instructed formally and is not recognized by the award of compensation 
or formal. Therefore, it can be concluded that OCB is the contribution of civil servants who exceed the formal job description and made freely, voluntarily, spontaneously, and not recognized by the reward system, but contribute to the effectiveness and efficiency of the functioning of the organization.

\section{Civil servants performance}

The individual performance is the result of work that can be achieved by a person or group of people within an organization in accordance with the authority and responsibilities of each in order to achieve the objectives of the organization legally, does not violate the law, and not contrary to morals and ethics (Riva, 2005), The views of other scholars, explaining the individual's performance as a sacrifice of body and mind services to produce goods or services in exchange for obtaining certain achievements (Hasibuan, 2001: 160). In the formal organization, the performance of individual employees or groups depending on their business and direction as well as the competence and motivation to show the performance as expected to achieve targets based on their position in the system (Bass \& Avolio, 1990).

\section{Methods}

This research uses explanatory research approach. Stratified random sampling is used to obtain a total of 156 civil servants working in Local Government Tana Toraja. Hypothesis testing is done by using the Structural equation modeling (SEM) with AMOS (Analysis of Moment Structures) software Ver.21

\section{Results}

The respondent's characteristics by gender, respondent's dominance are a male amount of 89 respondents, or $52.2 \%$. In other parts of the classification of respondents based on the age of the respondents was dominated at ages 31-40 years in the amount of 74 respondents, or $40.7 \%$

Table 1. Respondent characteristics

\begin{tabular}{|l|l|l|l|}
\hline Description & Criteria & Frequency & Percent \\
\hline \multirow{2}{*}{ Gender } & Male & 89 & 52,2 \\
& Female & 67 & 47,8 \\
\hline \multirow{5}{*}{ Ages (Years) } & $16-21$ & 13 & 14.8 \\
& $21-30$ & 22 & 5.6 \\
& $31-40$ & 74 & 40.7 \\
& $41-50$ & 20 & 11.1 \\
& $>50$ & 27 & 27.8 \\
\hline \multirow{5}{*}{ Educational level } & Doctoral & 1 & 0,6 \\
& Master & 5 & 3,2 \\
& Bachelor & 136 & 87,1 \\
& Diploma & 10 & 6,41 \\
& Senior high school & 2 & 1,2 \\
& Yunior school & 1 & 0,6 \\
& Primary school & 1 & 0,6 \\
\hline \multirow{5}{*}{ Job tenure (Years) } & $1-5$ & 60 & 38.5 \\
& $6-10$ & 35 & 22.4 \\
& $11-15$ & 29 & 18.6 \\
& $15-20$ & 15 & 9.6 \\
& $>20$ & 17 & 10.9 \\
\hline & I & 18 & 1.9 \\
& II & 88 & 75.9 \\
& III & 43 & 18.5 \\
& IV & 7.7 \\
\hline
\end{tabular}

Based on respondent's educational level is dominated by bachelor, as many as 136 respondents or $87.1 \%$ with tenure dominant 1 - 5 years of the 60 respondents. On the other hand based Rank / Group Respondents characterized in Group II as many as 88 respondents.

\section{Confirmatory factor analysis (CFA)}

Confirmatory factor analysis (CFA) is a multivariate statistical procedure that is used to test how well the measured variables represent the number of constructs. Confirmatory factor analysis (CFA) and exploratory factor analysis (EFA) are similar techniques, but in exploratory factor analysis (EFA), data is simply explored and provides information about the numbers of factors required to represent the data. In exploratory factor analysis, all measured variables are related to every latent variable. But in confirmatory factor analysis (CFA), researchers can specify the number of factors required in the data and which measured variable is related to which latent variable. Confirmatory factor analysis (CFA) is a tool that is used to confirm or reject the measurement theory. 
Leadership StyleThe leadership style variable qualified CFA testing $>0.60$ with the P-value of $<0.05$. The most important indicator in explaining leadership style shown in consultative leadership style that is equal to $77.80 \%$

Table 2. Leadership Style

\begin{tabular}{|l|l|l|l|l|}
\hline Measurement & Loading Factor $(\chi)$ & \multicolumn{1}{|c|}{ critical ratio } & P-value & Description \\
\hline Directive & 0.632 & 5.409 & 0.000 & Significant \\
\hline Consultative & 0.778 & 6.430 & 0.000 & Significant \\
\hline Participatory & 0.638 & 5.456 & 0.000 & Significant \\
\hline Delegations & 0.673 & FIX & 0.000 & Significant \\
\hline
\end{tabular}

Work motivation

Work motivation qualified CFA testing $>0.60$ with a P-value of $<0.05$. The most important indicator in explaining the motivation to work is shown in the indicator need for security that is equal to $79.30 \%$

Table 3. Work motivation

\begin{tabular}{|l|l|l|l|l|}
\hline Measurement & Loading Factor $(\chi)$ & critical ratio & P-value & Description \\
\hline Physiological Needs & 0.648 & 6.541 & 0.000 & Significant \\
\hline Need for security & 0.793 & 7.416 & 0.000 & Significant \\
\hline Need for actualization & 0.707 & 7.108 & 0.000 & Significant \\
\hline Need for affiliation & 0.659 & FIX & 0.000 & Significant \\
\hline
\end{tabular}

Local culture

The local cultural variables qualified testing of confirmatory factor analysis> 0.60 with a P-value of $<0.05$. The most important indicator in explaining the local culture is shown in the indicator Brave (Barani) that is equal to $97.00 \%$

Table 4. Local culture

\begin{tabular}{|l|l|l|l|l|}
\hline Measurement & Loading Factor $(\chi)$ & critical ratio & P-value & Description \\
\hline Wise (Kinaa) & 0.837 & Fix & 0.000 & Significant \\
\hline Rich (Sugi') & 0.888 & 14.766 & 0.000 & Significant \\
\hline Brave (Barani) & 0.970 & 16.158 & 0.000 & Significant \\
\hline
\end{tabular}

OCB

The OCB qualified testing of confirmatory factor analysis $>0.60$ with a P-value of $<0.05$. The most important indicator in explaining OCB Sportsmanship is shown in the dimension that is equal to $90.30 \%$

Table 5. OCB

\begin{tabular}{|l|l|l|l|l|}
\hline Measurement & Loading Factor $(\chi)$ & critical ratio & P-value & Description \\
\hline Altruism & 0.765 & Fix & 0.000 & Significant \\
\hline Conscientiousness & 0.896 & 14.196 & 0.000 & Significant \\
\hline Sportsmanship & 0.903 & 9.997 & 0.000 & Significant \\
\hline courtessy & 0.733 & 8.197 & 0.000 & Significant \\
\hline
\end{tabular}

Civil servants performance

Table 6. Civil servants performance

\begin{tabular}{|l|l|l|l|l|}
\hline Measurement & Loading Factor $(\chi)$ & critical ratio & P-value & Description \\
\hline Proactive in working & 0.911 & Fix & 0.000 & Significant \\
\hline good relationship & 0.960 & 19.489 & 0.000 & Significant \\
\hline skills and knowledge of the job. & 0.786 & 13.224 & 0.000 & Significant \\
\hline
\end{tabular}

This table describes that the indicators used to measure employee performance variables qualify the test confirmatory factor analysis $>0.60$ with a P-value of $<0.05$. The most important indicator in explaining employee performance indicators are shown in a good relationship that is equal to $96.00 \%$

\section{Model testing}

The final model test results above are evaluated based on the goodness of fit indices in the following table is equipped with the criteria of the model as well as critical values that have compatibility data. The results of the evaluation model proposed that the evaluation of the model to construct the overall turn out a variety of criteria already there is no violation critical, so do test the suitability of the model further. From the table above shows the value of the result meets the criteria fit so that SEM models were appropriate for use. 
Table 7. Overall Goodness of Fit Indices

\begin{tabular}{|l|l|l|l|}
\hline Goodness of fit index & Cut-off Value & Results Model & Specification \\
\hline $\mathrm{X}^{2}-$ Chi-Square & Expected small & 114.335 & Marginal \\
\hline Sig. Probability & $\geq 0.05$ & 0.421 & Good \\
\hline GFI & $\geq 0.90$ & 0.928 & Good \\
\hline AGFI & $\geq 0.90$ & 0.890 & Good \\
\hline TLI & $\geq 0.95$ & 0.998 & Good \\
\hline CFI & $\geq 0.95$ & 0.949 & Good \\
\hline RMSEA & $\leq 0.08$ & 0.068 & Good \\
\hline
\end{tabular}

\section{Hypothesis Testing}

The direct effect to evaluate each of the constructs of the direct effect which is a coefficient of all coefficients lines with arrows one end, the test results are presented. To find out how big between variables, then do the analysis of the direct and indirect effect as well as the total effect.

Table 8. Hypothesis

\begin{tabular}{|c|c|c|c|c|c|c|c|c|}
\hline \multirow{2}{*}{ No } & \multicolumn{3}{|l|}{ Variable } & \multirow{2}{*}{ P-Value } & \multirow{2}{*}{$\begin{array}{l}\text { Direct } \\
\text { Effect }\end{array}$} & \multirow{2}{*}{$\begin{array}{l}\text { Indirect } \\
\text { Effect }\end{array}$} & \multirow{2}{*}{$\begin{array}{l}\text { Total } \\
\text { Effect }\end{array}$} & \multirow{2}{*}{ Description } \\
\hline & exogenous & Intervening & endogenous & & & & & \\
\hline $\mathrm{H}_{1}$ & $\begin{array}{l}\text { Leadership Style } \\
\left(\mathrm{X}_{1}\right)\end{array}$ & - & $\begin{array}{l}\text { OCB } \\
(Y)\end{array}$ & 0.000 & 0.302 & 0.000 & 0.302 & Significant \\
\hline $\mathrm{H}_{2}$ & $\begin{array}{l}\text { Work Motivation } \\
\left(\mathrm{X}_{2}\right)\end{array}$ & - & $\begin{array}{l}\text { OCB } \\
(\mathrm{Y})\end{array}$ & 0.033 & .0 .150 & 0.000 & .0 .150 & Significant \\
\hline $\mathrm{H}_{3}$ & $\begin{array}{l}\text { Local Culture } \\
\left(\mathrm{X}_{3}\right)\end{array}$ & - & $\begin{array}{l}\text { OCB } \\
(Y)\end{array}$ & 0.000 & 0.688 & 0.000 & 0.688 & Significant \\
\hline $\mathrm{H}_{4}$ & $\begin{array}{l}\text { OCB } \\
(\mathrm{Y})\end{array}$ & - & $\begin{array}{l}\text { performance } \\
(\mathrm{Z})\end{array}$ & 0.005 & 0.315 & 0.000 & 0.315 & Significant \\
\hline $\mathrm{H}_{5}$ & $\begin{array}{l}\text { Leadership Style } \\
\left(\mathrm{X}_{1}\right)\end{array}$ & - & $\begin{array}{l}\text { performance } \\
\text { (Z) }\end{array}$ & 0.475 & 0.056 & 0.000 & 0.056 & Insignificant \\
\hline $\mathrm{H}_{6}$ & $\begin{array}{l}\text { Work Motivation } \\
\left(\mathrm{X}_{2}\right)\end{array}$ & - & $\begin{array}{l}\text { performance } \\
\text { (Z) }\end{array}$ & 0.157 & 0.095 & 0.000 & 0.095 & Insignificant \\
\hline $\mathrm{H}_{7}$ & $\begin{array}{l}\text { Local Culture } \\
\left(\mathrm{X}_{3}\right)\end{array}$ & - & $\begin{array}{l}\text { performance } \\
\text { (Z) }\end{array}$ & 0.000 & 0.433 & 0.000 & 0.433 & Significant \\
\hline $\mathrm{H}_{8}$ & $\begin{array}{l}\text { Leadership Style } \\
\left(\mathrm{X}_{1}\right)\end{array}$ & $\begin{array}{l}\text { OCB } \\
(\mathrm{Y})\end{array}$ & $\begin{array}{l}\text { performance } \\
\text { (Z) }\end{array}$ & 0.001 & 0.302 & 0.143 & 0.445 & Significant \\
\hline $\mathrm{H}_{9}$ & $\begin{array}{l}\text { Work Motivation } \\
\left(\mathrm{X}_{2}\right)\end{array}$ & $\begin{array}{l}\text { OCB } \\
(Y)\end{array}$ & $\begin{array}{l}\text { performance } \\
\text { (Z) }\end{array}$ & 0.045 & 0.150 & 0.057 & 0.207 & Significant \\
\hline $\mathrm{H}_{10}$ & $\begin{array}{l}\text { Local Culture } \\
\left(\mathrm{X}_{3}\right)\end{array}$ & $\begin{array}{l}\text { OCB } \\
(\mathrm{Y})\end{array}$ & $\begin{array}{l}\text { performance } \\
\text { (Z) }\end{array}$ & 0.000 & 0.688 & 0.234 & 0.922 & Significant \\
\hline
\end{tabular}

1. Leadership style is positive and significant effect on OCB

Testing Hypothesis $\left(\mathrm{H}_{1}\right)$ who stated that the leadership style influence on OCB is acceptable, because the results showed that the leadership style positive and significant effect on OCB this is evidenced in the table 20 with the path coefficients 0302 and the p-value of 0.000 or less than 0.05 . This means that if both the OCB leadership style would be good. A leader must have a consistent quality and attitude to be able to influence others so that others would follow. The leader has the authority to direct the activities of the member or group. Both the poor leader can be known of how leaders behave every day. On the other hand leadership style reasons positive and significant effect on OCB due to the fact that seen in Tana Toraja regency administration. Leaders can establish mechanisms to maintain develop or change OCB (Sportsmanship) there. Sportsmanship mechanism is taught by a leader through a consultative style, a good relationship with employees so as to improve the Sportsmanship is strong. It is certainly beneficial because the leadership can devote him to other things, this research supports the findings of previous investigators, that the better style of leadership shown proven leader able to increase OCB employee in the right direction (Sudirjo \& Kris, 2013; Prabowo \& Djastuti, 2014).

2. Work motivation positive and significant effect on OCB.

Testing Hypothesis $\left(\mathrm{H}_{2}\right)$ stated work motivation positive and significant impact on OCB is acceptable, because the results showed that the motivational effect on OCB this is evidenced in the table 8 with the path coefficients 0.150 and the p-value of 0.033 or less than 0.05 . It can be interpreted that if the motivation of both the OCB would be good. One thing that should be the main concern is the authority on how to keep and manage employee motivation in working order is always high and the focus on basic tasks and functions of each. Motivation is an indicator that is able to create a more satisfied employee in carrying out its activities. Work motivation positive and significant effect on OCB due to employees who have high motivation of this behavior is directed to the destination agencies and all forms of activity will not be easily disturbed by small disturbances

DOI: 10.9790/487X-2005035765 $\quad$ www.iosrjournals.org $\quad 61 \mid$ Page


which means that the stronger the influence of motivation, the OCB (Sportsmanship) higher. Sportsmanship can arise from various factors within the agency, including because of the motivation given to the employee in this case the Tana Toraja regency administration is due to the need for security can contribute to the Sportsmanship. This study supports the findings of previous investigators that motivation positive and significant effect on OCB (Danendra Nice \& Mujiati Ni Wayan, 2016; Lia Mayasari, 2013).

\section{Local culture positive and significant impact on organizational citizenship behavior.}

Testing Hypothesis $\left(\mathrm{H}_{3}\right)$ stating the local culture positive and significant effect on OCB is acceptable, because the results showed that the local culture positive and significant effect on organizational citizenship behavior, this is evidenced in the table 8 with the path coefficients 0,688 and the p-value of 0.000 or less than 0.05 . This means that if the local culture better, it will increase the OCB. Culture can describe the personality of a nation so that culture can describe the personality of a nation so that culture can make to the size of the advance of human civilization. The local culture contains values that are loaded with deep meanings and is highly valued by the people who hold them. The local culture is positive and significant effect on OCB due to employees who have a local culture that is high in this case Brave (Barani) may increase the effect of the increase in human resources better and local culture can change the mindsets of employees work beyond their means, and may contribute to the other in this case Sportsmanship in Tana Toraja regency administration. This study supports the findings of previous studies that the local culture is positive and significant effect on OCB, which means the better the culture of the organization that applied the OCB also higher (Jalismen, 2015).

\section{OCB positive and significant effect on civil servants performance.}

Testing Hypothesis $\left(\mathrm{H}_{4}\right)$ who stated that the OCB positive and significant effect on employee performance is acceptable, because the results showed that OCB positive and significant effect on civil servants performance as evidenced in the table 20 with the path coefficients 0,315 and the p-value of 0.005 or less than 0.05 . This may imply that the OCB contribute to employee performance. The effectiveness of an organization is determined by the behavior of the individuals in it. Such behavior includes not only in-role behavior, but is expected to further raise extra-role behavior of the individual. Extra-role behavior is often referred to as OCB. The Civil servants behavior is not part of the required duties formally. The quality and quantity result of civil servants in performing their duties in accordance with the responsibilities given to him. The reason of OCB is positive and significant effect on civil servants performance. This means that every employee in Tana Toraja regency administration has had in this case Sportsmanship OCB which will contribute to improving the performance of employees in this case relate well with employees in Tana Toraja regency administration. Research is in line with previous research findings that the higher the level OCB further improves the performance of employees (Anna Suzana, 2017; Kimball et al., 2015; Sanjaya, 2017).

\section{Leadership style positive and insignificant effect on civil servants performance.}

Testing Hypothesis $\left(\mathrm{H}_{5}\right)$ leadership style positive and significant effect on civil servants performance is denied, because the results showed that leadership style has a positive effect and insignificant effect on employee performance as evidenced in the table with path coefficients 0,056 and the p-value of 0.475 or greater than 0.05 . This may imply that the style of leadership does not contribute to employee performance. Leadership can be expressed as a way of being a leader in directing, encouraging and manage all elements within the agency to achieve a desired goal resulting in the employee's performance means the achievement of one's work or employees in realizing the objectives of the institution. The reason of leadership style positive and insignificant effect on civil servants performance due to the fact that seen in Tana Toraja regency administration. The leaders who led the consultative style will enhance the good relationship to employees, because without both agencies will not run perfectly. This study rejected the findings of previous research that proves that leadership style is positive and significant effect on employee performance (Sudirjo \& Kris, 2013).

6. Work motivation positive and insignificant effect on civil servants performance.

Testing Hypothesis $\left(\mathrm{H}_{6}\right)$ which stated that the motivation of positive and significant influence on employee performance is rejected, because the results showed that the motivation of positive and significant influence on employee performance as evidenced in the table 8 with the path coefficients 0.095 and the p-value of 0.157 or greater than 0.05 . This may imply that motivation does not contribute to employee performance. In establishments there are many people with many motives and objectives. If an error occurs in the management then it would cause various problems. Among the problems arising from aspects of human resources is a decrease in work motivation. Employee motivation is very low, if left unchecked will affect the performance of employees. The lack of work motivation is no significant effect on employee performance due to the fact that seen in Tana Toraja regency administration. Leaders always give a sense of security to the employees to create a good relationship to employees, because without that agency will not run perfectly because an unsatisfied need 
creates tension which stimulates impulse within oneself. This study rejected the findings of previous investigators, that the higher the level of motivation that reflect improvement in employee performance. Therefore, it is required of employees who have high motivation to work for someone who has a high motivation to work will get optimal results, so that a job will be done properly (Sutrisno et al., 2016; Mahardhika, 2012).

\section{Local culture positive and significant effect on civil servants performance.}

Testing Hypothesis $\left(\mathrm{H}_{7}\right)$ which states that local culture positive and significant effect on employee performance is acceptable, because the results showed that the local culture positive and significant effect on employee performance as evidenced in the table 8 with the path coefficients 0,433 and the p-value of 0.000 or less than 0.05 . This may imply that the presence of the local culture then it will increase the performance of employees. The humans as social beings cannot live alone without any help from others, because it is people are always interacting with the surrounding environment. The interaction between civil servants with co-workers that the miscellaneous culture. Humans evolved with all its potential, thereby causing interaction between groups is growing as well. Factors causing the local culture positive and significant impact on employee performance due to the fact that seen in Tana Toraja regency administration brave culture (Barani) can improve both the employee relationship. Brave culture is a system of beliefs and values shared within the organization or institution that disseminated within the agency that then referred to as the philosophy of all employees. This study is consistent with previous studies that the local culture positive and significant influence on employee performance. This means that the increased attitude brave (Barani) then the level of leadership, a leader then reflecting an increase in civil servants relations are good (Rante, 2011).

\section{Leadership style significant effect on civil servants performance. The mediating role of OCB}

Testing Hypothesis $\left(\mathrm{H}_{8}\right)$ stated that the Leadership style significant effect on civil servants performance. The mediating role of OCB is acceptable, Because The results Showed that the local culture positive and significant effect on employee performance as evidenced in the table 8 with the path coefficients 0,302 and the p-value of 0,001 or less than 0,05 . This means that with the style of leadership that will improve the performance of employees with the support of OCB. The achievement of organizational goals that are economic, social and political is largely dependent on the ability of the leaders in the organizational units concerned. Leadership is very important for the organization, where the leadership is an attempt to influence others to act in the desired direction. Leadership is a tool for managing organizational change. Factors causing the leadership style influence is not direct and significant impact on employee performance through OCB due to the fact that seen in the Regional Government of Tana Toraja leaders who lead by force of consultative will promote good relations to the employee but if through Sportsmanship is not appropriate because if there is a new policy on one thing, workers who have high sportsmanship attitude then the employee will not easily accept the new policy and raising minor problems that may arise due to the new policy. This study supports the findings of other researchers that leadership style is positive and significant effect on employee performance (Sudirjo \& Kris, 2013).

\section{Work motivation significant effect on civil servants performance. The mediating role of OCB}

Testing Hypothesis $\left(\mathrm{H}_{9}\right)$ stated that the Work motivation significant effect on civil servants performance. The mediating role of OCB is acceptable, because the results showed that the motivational effect is not direct and significant impact on employee performance through OCB this is evidenced in the table 8 with the path coefficients 0,150 and the p-value of 0.045 or less than 0.05 . This may imply that the motivation will increase employee performance through OCB. Directions behavior is a behavior that has someone in work, measured by their desire to finish the job and adherence to regulations. The level of effort regarding how hard a person to work in accordance with the behavior that has been measured by the seriousness of the work and the desire to be better than ever or the process in which the need to encourage a person to perform a series of activities that lead to the achievement of certain goals. Factors causing significant motivation and a positive effect on employee performance OCB due to the fact that seen in Tana Toraja District Government leaders always give a sense of security to the employee up to the creation of good relations on an employee without the support of Sportsmanship, because without Sportsmanship agency will run. Therefore, it is required of employees who have high motivation at work because generally the Tana Toraja regency administration has great expectations so that employees can enhance better performance and effective in performing responsibilities to his job. These results support the findings of previous researchers that higher levels of motivation that reflect improvement in the performance of employees (Argensia et al., 2014; Sutrisno, 2016; Rangga Mahardhika, 2012).

10. Local culture significant effect on civil servants performance. The mediating role of OCB 
The Hypothesis $\left(\mathrm{H}_{10}\right)$ which states that the local culture is significant effect on civil servants performance. The mediating role of OCB is acceptable, because the results showed that the local culture indirect effect and significant impact on employee performance through OCB this is evidenced in the table 8 with the path coefficients 0.0 .688 and the p- value of 0,000 or less than 0.05 . This may imply that the presence of the local culture will increase if the employee's performance through OCB. Every organization has their own cultural characterizes an organization. Local culture plays a fairly important in the organization as a good culture will be able to give comfort then support an increase in the performance of their employees. It has become one differentiator between the organizations. Factors that cause the local culture is significant impact on employee performance through OCB due to employees who have a local culture that is high in this case brave (barani) may increase the effect of the increase in human resources better and local culture can change the mindsets of employees work more beyond its means, and can contribute to the other in this case a good relationship with an employee of the District Government of Tana Toraja. This study supports the findings of previous researchers that the local culture is positive and significant effect on the OCB, which means the better the culture of the organization that applied the OCB also higher (Jalismen, 2015).

\section{Conclusion}

Leadership style that consists of indicators: directive, consultative, participatory and delegations as well as significant positive effect on organizational citizenship behavior. This means that if both the OCB leadership style would be good. Motivation consists of indicators: the physiological needs of the need for security, the need for actualization and the need for affiliation and significant positive effect on organizational citizenship behavior. It can be interpreted that if the motivation of both the organizational citizenship behavior will be good. Local culture consisting of: Wise (Kinaa), Rich (Sugi), and brave (Barani) is a significant positive effect on OCB. This means that if the local culture better, it will increase the OCB. OCB consisting of the dimensions Altruism, Conscientiousness, Sportsmanship and courtesy as well as a significant positive effect on employee performance, it can be interpreted that the OCB contribute to employee performance. Leadership style which consists of indicators: directive, consultative, participatory and delegations as well as no significant positive effect on employee performance, it can be interpreted that the style of leadership does not contribute to employee performance. Motivation consisting of indicators: the physiological needs of the need for security, the need for actualization and the need for affiliation and no significant positive effect on employee performance, it can be interpreted that motivation does not contribute to employee performance.

Local culture is a significant positive effect on employee performance; it can be interpreted that the presence of the local culture then it will increase the performance of employees. The leadership style is not a direct and significant effect on the performance of employees through the OCB; it can be interpreted that with the style of leadership that will increase the performance of employees if through OCB. Motivation is not a direct and significant effect on the performance of employees through the OCB; this may imply that the motivation will increase employee performance through OCB. Local culture is not a direct and significant effect on the performance of employees through the OCB, This may imply that the presence of the local culture will increase if the employee's performance through OCB. Leadership style should be more on the increase again in order to give rise to the OCB. Increased employee motivation can give a good impact on OCB. Program owned by the Regional Government of Tana Toraja is expected to boost the local culture in the public interest or the public as well as the direction, goals, objectives and clear work procedures that can be understood by all employees and can improve organizational citizenship behavior.

Creating awareness to the employees of the OCB will improve employee performance. Leaders should not hesitate to give an example of a good performance and motivate employees in doing a job to improve employee performance. Giving full support to each employee will improve local cultural values and defend it until finally improve employee performance. Improved leadership style can be improving civil servants performance through increased OCB employee in the scope of the Regional Government of Tana Toraja. The high of work motivation and the good local culture can be improving civil servants performance through OCB.

\section{References}

[1]. Aldag, R., \& Reschke, W. (1997). Employee value added: Measuring discretionary effort and its value to the organization. Center for Organization Effectiveness, 1-8.

[2]. Bass, BM, \& Avolio, BJ (1990). Transformational leadership development: A Manual for the multifactor leadership questionnaire. Consulting Psychologists Press.

[3]. Brown, DR, \& Harvey, DF (2011). An experiential approach to organization development.

[4]. Chatab, Nevizond, (2007), Organizational Culture Profile Bandung: Alfabeta.

[5]. Danendra Bagus Ngurah \& Mujiati AA Ni Wayan. (2016). Effect of Motivation, Compensation and Organizational Commitment to Organzatinoal Citizenship Behavior (OCB). E-Journal of Management Udayana University, Vol. 5, No. 10, 2016: 6229-6259, ISSN: 2302-8912.

[6]. Darsana, M. (2013). The influence of personality and organizational culture on employee performance through organizational citizenship behavior. The International Journal of Management, 2 (4), 35-42. 
[7]. Davis, Keith \& John W. Newstrom. (2005). Behavior in Organizations. Jakarta: Erland

[8]. Gibson (1995). Organization and Management, Second Edition, four, Jakarta: Erland.

[9]. Hardaningtyas, Dwi, (2004). "Effect of Emotional Intelligence and Attitudes On Organizational Culture on Organizational Citizenship Behavioral (OCB)." Thesis, University of Airlangga, Surabaya.

[10]. Hasibuan, Malay SP (2001). Human Resource Management. Jakarta: PT. Earth Literacy

[11]. Hasibuan, MSP (2006). Human Resource Management. Revised Edition, Jakarta: Earth Literacy.

[12]. Hofstede, Geert, January Gert Hofstede, and Michael Minkov. (2010). Cultures and Organizations3rd edition. New York: Mc GrawHill.

[13]. Jalismen, M. (2015). Influence of Organizational Culture and Organizational Citizenship Behavior Against Ethics (Ocb) Master SMA In Sipora Mentawai Islands. Journal of Management Education, 6 (1), 1007-1016.

[14]. Kim, MH, Kim, AH, \& Song, EJ (2014). The relationship between authentic leadership, trust in the leader and the OCB of the hotel restaurant. Journal of Foodservice Management Society of Korea, 17 (2), 117-134.

[15]. Kimball, FF, Sendow, GM, \& Adare, DJ (2015). Workload, Organizational Citizenship Behavior and Work Engagement Effect on Employee Performance PT. PLN (Persero) Region Area Suluttenggo Manado. EMBA Journal: Journal of Economic Research, Management, Business and Accounting, 3 (2).

[16]. Kobong, (1992). Indigenous and Cultural aluk Toraja in encounter with the Gospel. Tana Toraja: Toraja Church Development Center.

[17]. Lia Mayasari, D. (2013). Influence of Work Motivation, Work Against Loyalty Organizational Citizenship Behavior (OCB) and Employee Performance at the Central Office Sugai Watershed Management Sampean In the regency.

[18]. Mahardhika, R. (2013). Influence of Work Motivation on Employee Performance (Survey of Employees at PT. Axa Financial Indonesia Sales Office Malang). Journal of Business Administration, 4 (2)

[19]. Markoczy, L., \& Xin, K. (2002). The virtues of omission in Organizational Citizenship Behavior., 1:14 version.

[20]. Podsakoff, PM, MacKenzie, SB, Paine, JB, \& Bachrach, DG (2000). Organizational citizenship behaviors: A critical review of the theoretical and empirical literature and suggestions for future research. Journal of Management, 26 (3), 513-563.

[21]. Prabowo, A., \& Djastuti, I. (2014). Analysis of Effect of Transformational Leadership and Job Satisfaction on Organizational Citizenship Behavior (OCB) with the Organizational Commitment as an intervening variable (Studies in Hospital Nurses Kariadi, Semarang) (Doctoral dissertation, Faculty of Economics and Business).

[22]. Rante, Y. (2011). Ethnic and cultural influences entrepreneurial behavior on the performance of small micro agribusiness in Papua province. Journal of Management and Entrepreneurship, 12 (2), pp 133.

[23]. Rival, Veithzal. (2005). Human Resource Management. Jakarta: King Grafindo Persada.

[24]. Robbins, Stepen P. (2002). Management $7^{\text {th }}$ Edition. Prentice Hall International. New Jersey.

[25]. Sanjaya, R. (2017). Influence Analysis of Organizational Citizenship Behavior and Organizational Trust on Employee Performance In Mie Satan Kober Surabaya. Agora, 5 (3).

[26]. Sjahruddin, H., \& Normijati, AAS (2013). Personality effect on organizational citizenship behavior (OCB): trust in manager and organizational commitment of organizational justice mediator in Makassar City Hospitals (Indonesia). European Journal of Business and Management, 5 (9), 95-104

[27]. Sjahruddin, H., \& Sudiro, AA (2013). Organizational justice, organizational commitment and trust in manager as predictors of organizational citizenship behavior. Interdiciplinary J. of contemporary Res. Bus. (IJCRB), 4 (12), 133-141.

[28]. Sudirjo, F., \& Kris, T. (2013). Influence of Organizational Culture, Leadership Style and Job Satisfaction on Employee Performance With Organizational Commitment As Variable Interverning (Studies in Hospital PT VALE Soroako, South Sulawesi). Scientific Journal of UNTAG Semarang.

[29]. Sudirjo, F., \& Kris, T. (2013). Influence of Organizational Culture, Leadership Style and Job Satisfaction on Employee Performance With Organizational Commitment As Variable Interverning (Studies in Hospital PT VALE Soroako, South Sulawesi). Scientific Journal of UNTAG Semarang.

[30]. Sutrisno, S., Fathoni, A., \& Minarsih, MM (2016). Motivation and Work Discipline influence on employee performance in the Office of Civil Service Police Unit of Semarang. Journal of Management, 2 (2).

[31]. Suzana, A. (2017). Influence of Organizational Citizenship Behavior (OCB) on Employee Performance (Study At PT. TASPEN (Persero) Branch Cirebon). Logic, 19 (1), 42-50.

[32]. Winardi. (2000). Leadership in management. Jakarta. Rineka Cipta

Althon Karaman Pongtuluran "The Effect of Leadership Style, Work Motivation and Local Culture on Organizational Citizenship Behavior and Civil Servants Performance." IOSR Journal of Business and Management (IOSR-JBM) 20.5 (2018): 57-65. 